\title{
Amidopoly Ethylamines as Corrosion Inhibitors for Zinc Dissolution in Different Acidic Electrolytes
}

\author{
M. Abdallah, ${ }^{*}$ A.Y. El-Etre, M.F. Moustafa \\ Department of Chemistry, Faculty of Science, Benha University, Benha, Egypt.
}

\begin{abstract}
The effect of some amidopoly ethylamine, with different numbers of ethylamine units, on the corrosion of zinc electrode in $\mathrm{ZnCl}_{2}, \mathrm{NH}_{4} \mathrm{Cl}$ and $\left(\mathrm{ZnCl}_{2}+\mathrm{NH}_{4} \mathrm{Cl}\right)$ electrolytes has been studied using galvanostatic polarization measurements. The inhibition efficiency was found to increase with increasing concentration, number of ethylamine units per molecule and with decreasing the temperature. Inhibition is explained on the basis of adsorption of amidopoly ethylamine molecules on the zinc electrode surface through their ethylamine groups. The inhibitors are adsorbed on the zinc electrode surface according to Langmuir adsorption isotherm. Some thermodynamic parameters are calculated and explained for the tested systems from the data obtained at different temperatures.
\end{abstract}

Keywords: zinc, corrosion inhibitors, amidopoly ethylamine, $\mathrm{ZnCl}_{2}, \mathrm{NH}_{4} \mathrm{Cl}$, adsorption.

\section{Introduction}

Zinc metal is used in many practical applications such as a favorable anode for primary dry batteries [1], a coating for carbon steel and alloying element in electrical contacts [2]. Due to relatively low price, high discharge efficiency and high safety features associated with its manufacturing processes and use, its protection against corrosion has attracted much attention. Mercury is widely used as inhibitor for corrosion of zinc electrode in zinc-manganese batteries [3], but it causes severe pollution because of its high toxicity. With increasing concern about pollution control, the use of mercury in batteries is to be replaced. The use of inhibitors is one of the most practical method for protection against corrosion especially in acidic media [4-12]. Most of well-known corrosion inhibitors are organic compounds containing nitrogen, sulphur and oxygen atoms [13-18]. Such compounds contain electron-donating groups, which decrease the corrosion rate

\footnotetext{
* Corresponding author. E-mail address: metwally552@ hotmail.com
} 
by increasing the hydrogen overpotential on the corroding metal [19]. The effectiveness of such compounds as inhibitors generally increases with increasing chain length [20-22].

The present work aims to study the effect of four compounds of amidopoly ethylamine, which have surface active properties, as inhibitors for the corrosion of zinc used in zinc-manganese battery electrolytes $\mathrm{ZnCl}_{2}, \mathrm{NH}_{4} \mathrm{Cl}$ and $\left(\mathrm{ZnCl}_{2}+\right.$ $\mathrm{NH}_{4} \mathrm{Cl}$ ). The effect of increasing of the ethylamine units contained in the chemical structure of the used compounds on the inhibition efficiency is studied. Moreover, the effect of temperature on the dissolution of zinc electrode as well as on the inhibition efficiency of the used compounds is also investigated.

\section{Experimental method}

Zinc electrodes are fabricated from battery grade zinc disk sealed in araldite resin with an exposed surface area of $0.385 \mathrm{~cm}^{2}$. The electrode which is composed of $\mathrm{Zn}(99.35 \%), \mathrm{Pb}(0.5 \%), \mathrm{Cd}(0.003 \%)$ and $\mathrm{Fe}(0.002 \%)$, was supplied by Kaha company for chemical industries (Egypt). The electrode surface was polished with different grades of emery papers 600 and 1200, degreased with acetone and rinsed with distilled water. AR grade zinc chloride and ammonium chloride were used for preparing the test solutions.

The four amidopoly ethylamine compounds are prepared using a simple method described elsewhere [23]. They have the general formula:

\section{R-CONH-[- $\left.\mathrm{CH}_{2} \mathrm{CH}_{2} \mathrm{NH}-\right]_{\mathrm{n}}-\mathrm{H}$}

where, $\mathrm{R}$ is $\mathrm{C}_{16} \mathrm{H}_{33}$ and $\mathrm{n}$ is the number of ethylamine units (EA). The numbers of (EA) per molecule of amide are 2, 3, 4, and 5 for compounds I, II, III and IV, respectively. The used surfactant compounds in the present work are cationic, which form positive charges at their heads when dissolved in water.

Anodic and cathodic Tafel polarization experiments are preformed using economical potentiostat Voltalab 21, PGP 201. The electrolytic cell was a threenecked glass bottle fitted with a platinum counter electrode, a saturated calomel electrode (SCE) as reference electrode, and the working zinc electrode.

\section{Results and discussion \\ Galvanostatic polarization measurements}

The effect of addition of amidopoly ethylamine on the anodic and cathodic polarization curves of zinc electrode in $0.1 \mathrm{M} \mathrm{ZnCl}_{2}, 0.1 \mathrm{M} \mathrm{NH}_{4} \mathrm{Cl}$ and $(0.1 \mathrm{M}$ $\mathrm{ZnCl}_{2}+0.1 \mathrm{M} \mathrm{NH}_{4} \mathrm{Cl}$ ) solutions at $25{ }^{\circ} \mathrm{C}$ is studied. The effect of increased concentration of compound IV in $0.1 \mathrm{M} \mathrm{ZnCl}_{2}$ is represented in Fig. 1 as an example. However, similar curves for other solutions were also obtained (not shown).

An inspection of the curves in Fig. 1 reveals that the presence of increasing concentration of the inhibitor shifted the anodic current/potential curves in the anodic direction and cathodic curves in the cathodic direction.

Tables 1-3 present the corrosion parameters of zinc electrode in $0.1 \mathrm{M} \mathrm{ZnCl}_{2}, 0.1$ 
$\mathrm{M} \mathrm{NH} \mathrm{NH}_{4}$ and $\left(0.1 \mathrm{M} \mathrm{ZnCl}_{2}+0.1 \mathrm{M} \mathrm{NH} \mathrm{Cl}_{4}\right)$ solutions, respectively. These parameters are anodic Tafel slope $\left(b_{a}\right)$, cathodic Tafel slope $\left(b_{c}\right)$, corrosion potential $\left(\mathrm{E}_{\text {corr }}\right)$, corrosion current $\left(\mathrm{i}_{\text {corr }}\right)$ and inhibition efficiency (I.E.). The corrosion current density $\left(\mathrm{i}_{\text {corr }}\right)$ is calculated by the extrapolation of anodic and cathodic Tafel lines with the steady state (corrosion) potential ( $\mathrm{E}_{\text {corr. }}$ ). The inhibition efficiency was calculated using the following equation:

$$
\mathrm{IE}=100\left[1-\left(i_{\text {add }} / i_{\text {free }}\right)\right]
$$

where, $i_{\text {add }}$ and $i_{\text {free }}$ are the corrosion current of zinc electrode in the presence and in the absence of inhibitors, respectively.

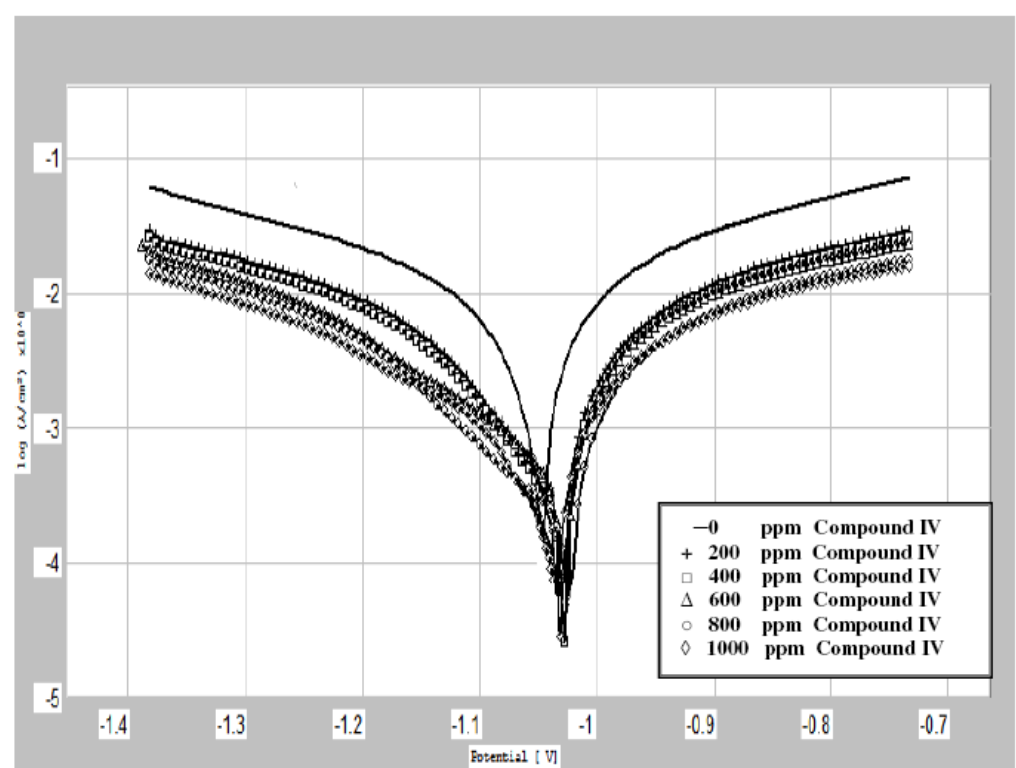

Figure 1. Anodic and cathodic polarization curves of $\mathrm{Zn}$ electrode in $0.1 \mathrm{M} \mathrm{ZnCl}_{2}$ solution containing different concentrations of compound IV at $25{ }^{\circ} \mathrm{C}$.

Inspection of Tables 1-3 reveals that: the value of $\mathrm{i}_{\text {corr. }}$ in case of $\left(\mathrm{ZnCl}_{2}+\right.$ $\mathrm{NH}_{4} \mathrm{Cl}$ ) was higher than that obtained in $\mathrm{NH}_{4} \mathrm{Cl}$ and less than that obtained in $\mathrm{ZnCl}_{2}$ of the same concentration. This indicates that, both $\mathrm{ZnCl}_{2}$ and $\mathrm{NH}_{4} \mathrm{Cl}$ accelerate the corrosion of zinc electrode. The combined effect of $\mathrm{ZnCl}_{2}$ and $\mathrm{NH}_{4} \mathrm{Cl}$ on the corrosion of zinc electrode is greater than that caused by $\mathrm{NH}_{4} \mathrm{Cl}$ and less than that caused by $\mathrm{ZnCl}_{2}$.

The corrosion potential shifted to less negative values and $i_{\text {corr }}$ decreased when the concentration of amidopoly ethylamine was increased, indicating the inhibiting effect of these compounds.

The IE increased with increasing concentration of additives and number of ethylamine units per molecule of the additive. The inhibition efficiencies of the four tested compounds measured by the galvanostatic polarization measurements decreased in the following order:

Compound IV > Compound III > Compound II > Compound I

Furthermore both anodic and the cathodic Tafel slopes increase upon addition of the inhibitors. This result suggests that the used surfactant compounds act as 
mixed inhibitors.

Table 1. Corrosion parameters of $\mathrm{Zn}$ electrode in $0.1 \mathrm{M} \mathrm{ZnCl}_{2}$ solution containing different concentrations of inhibitors.

\begin{tabular}{|c|c|c|c|c|c|}
\hline Medium & $\begin{array}{c}\mathbf{b}_{\mathbf{a}} \times \mathbf{1 0}^{-2} \\
(\mathrm{mV} / \text { decade })\end{array}$ & $\begin{array}{c}\mathbf{b}_{\mathbf{c}} \times \mathbf{1 0}^{-2} \\
(\mathrm{mV} / \text { decade })\end{array}$ & $\begin{array}{c}-\mathbf{E}_{\text {corr. }} \\
\mathrm{mV} \text { (S.C.E.) }\end{array}$ & $\begin{array}{c}\mathbf{i}_{\text {corr. }} \times \mathbf{1 0}^{-1} \\
(\mathrm{~mA})\end{array}$ & $\begin{array}{l}\text { I.E. } \\
(\%)\end{array}$ \\
\hline \multicolumn{6}{|l|}{$0.1 \mathrm{M} \mathrm{ZnCl}_{2}+$ compound $\mathrm{I}$} \\
\hline 0.0 ppm compound I & 153 & 280 & 1046 & 33.5 & -- \\
\hline 200 pp & 397 & 289 & 1039 & 24.7 & 26.3 \\
\hline 400 ppm compound I & 425 & 305 & 1039 & 19.1 & 42.9 \\
\hline 600 ppm compound I & 434 & 307 & 1039 & 15.3 & 54.3 \\
\hline 800 ppm compound I & 442 & 322 & 1039 & 13.9 & 58.5 \\
\hline 1000 ppm compound I & 443 & 323 & 1039 & 12.3 & 63.3 \\
\hline \multicolumn{6}{|l|}{$0.1 \mathrm{M} \mathrm{ZnCl}_{2}+$ compound II } \\
\hline 0.0 ppm compound II & 153 & 280 & 1046 & 33.5 & -- \\
\hline 200 ppm compound II & 410 & 291 & 1033 & 21.0 & 37.3 \\
\hline 400 ppm compound II & 430 & 310 & 1033 & 14.5 & 56.8 \\
\hline 600 ppm compound II & 520 & 320 & 1033 & 12.8 & 61.7 \\
\hline 800 ppm compound II & 521 & 322 & 1033 & 10.5 & 68.6 \\
\hline 1000 ppm compound II & 571 & 324 & 1033 & 8.9 & 73.4 \\
\hline \multicolumn{6}{|l|}{$0.1 \mathrm{M} \mathrm{ZnCl}_{2}+$ compound III } \\
\hline 0.0 ppm compound III & 153 & 280 & 1046 & 33.5 & -- \\
\hline 200 ppm compound III & 416 & 288 & 1031 & 17.7 & 47.1 \\
\hline 400 ppm compound III & 476 & 305 & 1031 & 11.1 & 66.8 \\
\hline 600 ppm compound III & 526 & 319 & 1031 & 9.5 & 71.6 \\
\hline 800 ppm compound III & 571 & 328 & 1031 & 8.3 & 75.2 \\
\hline 1000 ppm compound III & 590 & 354 & 1031 & 7.1 & 78.9 \\
\hline \multicolumn{6}{|l|}{$0.1 \mathrm{M} \mathrm{ZnCl}_{2}+$ compound IV } \\
\hline 0.0 ppm compound IV & 153 & 280 & 1046 & 33.5 & -- \\
\hline 200 ppm compound IV & 666 & 366 & 1027 & 13.6 & 59.5 \\
\hline 400 ppm compound IV & 666 & 407 & 1027 & 9.9 & 70.3 \\
\hline 600 ppm compound IV & 790 & 418 & 1027 & 7.5 & 77.5 \\
\hline 800 ppm compound IV & 782 & 427 & 1027 & 6.4 & 80.8 \\
\hline 1000 ppm compound IV & 792 & 427 & 1027 & 5.4 & 84.0 \\
\hline
\end{tabular}


Table 2. Corrosion parameters of $\mathrm{Zn}$ electrode in $0.1 \mathrm{M} \mathrm{NH}_{4} \mathrm{Cl}$ solution containing different concentrations of inhibitors.

\begin{tabular}{|c|c|c|c|c|c|}
\hline Medium & $\begin{array}{c}\mathbf{b}_{\mathbf{a}} \times \mathbf{1 0}^{-2} \\
(\mathrm{mV} / \text { decade })\end{array}$ & $\begin{array}{c}\mathbf{b}_{\mathbf{c}} \times \mathbf{1 0}^{-2} \\
(\mathrm{mV} / \text { decade })\end{array}$ & $\begin{array}{c}-\mathbf{E}_{\text {corr. }} \\
\mathrm{mV} \text { (S.C.E.) }\end{array}$ & $\begin{array}{c}\mathbf{i}_{\text {corr. }} \times 1^{-3} \\
(\mathrm{~mA})\end{array}$ & $\begin{array}{l}\text { I.E. } \\
(\%)\end{array}$ \\
\hline \multicolumn{6}{|l|}{$0.1 \mathrm{M} \mathrm{NH}_{4} \mathrm{Cl}+$ compound $\mathrm{I}$} \\
\hline 0.0 ppm compound I & 824.2 & 402.9 & 1145 & 39.9 & -- \\
\hline 200 ppm compound I & 1201.3 & 428.7 & 1135 & 32.0 & 19.7 \\
\hline 400 ppm compound I & 1201.3 & 458.3 & 1130 & 26.1 & 34.5 \\
\hline 600 ppm compound I & 1195.2 & 350.3 & 1127 & 22.2 & 44.3 \\
\hline 800 ppm compound I & 1176.1 & 364.0 & 1125 & 19.6 & 50.8 \\
\hline 1000 ppm compound I & 1115.4 & 385.0 & 1122 & 17.7 & 55.6 \\
\hline \multicolumn{6}{|c|}{$0.1 \mathrm{M} \mathrm{NH}_{4} \mathrm{Cl}+$ compound II } \\
\hline 0.0 ppm compound II & 824.2 & 402.9 & 1145 & 39.9 & -- \\
\hline 200 ppm compound II & 994.4 & 376.7 & 1134 & 30.6 & 23.3 \\
\hline 400 ppm compound II & 1081.0 & 334.1 & 1133 & 24.2 & 39.3 \\
\hline 600 ppm compound II & 1113.8 & 339.7 & 1130 & 20.2 & 49.3 \\
\hline 800 ppm compound II & 1235.5 & 343.9 & 1130 & 17.9 & 55.1 \\
\hline 1000 ppm compound II & 1193.6 & 347.4 & 1130 & 16.1 & 59.6 \\
\hline \multicolumn{6}{|c|}{$0.1 \mathrm{M} \mathrm{NH}_{4} \mathrm{Cl}+$ compound III } \\
\hline 0.0 ppm compound III & 824.2 & 402.9 & 1145 & 39.9 & -- \\
\hline 200 ppm compound III & 1753.7 & 196.3 & 1123 & 29.1 & 27.1 \\
\hline 400 ppm compound III & 1762.1 & 498.2 & 1123 & 22.1 & 44.6 \\
\hline 600 ppm compound III & 1932.3 & 498.2 & 1123 & 18.4 & 53.8 \\
\hline 800 ppm compound III & 1917.1 & 477.0 & 1123 & 16.0 & 59.8 \\
\hline 1000 ppm compound III & 1195.5 & 456.6 & 1123 & 14.6 & 63.4 \\
\hline \multicolumn{6}{|c|}{$0.1 \mathrm{M} \mathrm{NH}_{4} \mathrm{Cl}+$ compound IV } \\
\hline 0.0 ppm compound IV & 824.2 & 402.9 & 1145 & 39.9 & -- \\
\hline 200 ppm compound IV & 1899.2 & 430.0 & 1129 & 26.6 & 33.3 \\
\hline 400 ppm compound IV & 1977.5 & 457.8 & 1125 & 19.8 & 50.3 \\
\hline 600 ppm compound IV & 2010.8 & 454.0 & 1125 & 16.4 & 58.8 \\
\hline 800 ppm compound IV & 2011.8 & 455.0 & 1125 & 13.9 & 65.1 \\
\hline $1000 \mathrm{ppm}$ compound IV & 2013.6 & 448.8 & 1125 & 12.6 & 68.4 \\
\hline
\end{tabular}


Table 3. Corrosion parameters of $\mathrm{Zn}$ electrode in $\left(0.1 \mathrm{M} \mathrm{ZnCl} 2+0.1 \mathrm{M} \mathrm{NH} \mathrm{NH}_{4} \mathrm{Cl}\right)$ solution containing different concentrations of inhibitors.

\begin{tabular}{|c|c|c|c|c|c|}
\hline Medium & $\begin{array}{c}\mathbf{b}_{\mathbf{a}} \times \mathbf{1 0}^{-2} \\
(\mathrm{mV} / \text { decade })\end{array}$ & $\begin{array}{c}\mathbf{b}_{\mathbf{c}} \times \mathbf{1 0}^{-2} \\
(\mathrm{mV} / \text { decade })\end{array}$ & $\begin{array}{c}\mathbf{E}_{\text {corr. }} \\
\mathrm{mV} \text { (S.C.E.) }\end{array}$ & $\begin{array}{c}\mathbf{i}_{\text {corr. }} \times \mathbf{1 0}^{-1} \\
(\mathrm{~mA})\end{array}$ & $\begin{array}{l}\text { I.E. } \\
(\%)\end{array}$ \\
\hline \multicolumn{6}{|c|}{$\left(0.1 \mathrm{M} \mathrm{ZnCl}_{2}+0.1 \mathrm{M} \mathrm{NH}_{4} \mathrm{Cl}\right)+$ compound $\mathrm{I}$} \\
\hline 0.0 ppm compound I & 384 & 211 & 1045 & 30.2 & -- \\
\hline 200 ppm compound I & 366 & 226 & 1045 & 21.8 & 27.8 \\
\hline 400 ppm compound I & 419 & 237 & 1044 & 17.9 & 40.7 \\
\hline 600 ppm compound I & 437 & 247 & 1044 & 14.7 & 51.3 \\
\hline 800 ppm compound I & 467 & 260 & 1044 & 13.6 & 54.9 \\
\hline 1000 ppm compound I & 485 & 278 & 1040 & 11.8 & 60.9 \\
\hline \multicolumn{6}{|c|}{$\left(0.1 \mathrm{M} \mathrm{ZnCl}_{2}+0.1 \mathrm{M} \mathrm{NH}_{4} \mathrm{Cl}\right)+$ compound II } \\
\hline 0.0 ppm compound II & 384 & 211 & 1045 & 30.2 & -- \\
\hline 200 ppm compound II & 366 & 226 & 1045 & 20.9 & 30.7 \\
\hline 400 ppm compound II & 419 & 237 & 1045 & 16.2 & 46.3 \\
\hline 600 ppm compound II & 437 & 247 & 1043 & 13.5 & 55.2 \\
\hline 800 ppm compound II & 467 & 260 & 1043 & 11.5 & 61.9 \\
\hline 1000 ppm compound II & 485 & 278 & 1043 & 10.3 & 65.8 \\
\hline \multicolumn{6}{|c|}{$\left(0.1 \mathrm{M} \mathrm{ZnCl}_{2}+0.1 \mathrm{M} \mathrm{NH}_{4} \mathrm{Cl}\right)+$ compound III } \\
\hline 0.0 ppm compound III & 384 & 211 & 1045 & 30.2 & -- \\
\hline 200 ppm compound III & 377 & 231 & 1040 & 17.3 & 42.7 \\
\hline 400 ppm compound III & 403 & 250 & 1040 & 13.3 & 55.9 \\
\hline 600 ppm compound III & 456 & 252 & 1040 & 11.4 & 62.2 \\
\hline 800 ppm compound III & 541 & 291 & 1039 & 9.9 & 67.2 \\
\hline 1000 ppm compound III & 493 & 277 & 1039 & 8.8 & 70.8 \\
\hline \multicolumn{6}{|c|}{$\left(0.1 \mathrm{M} \mathrm{ZnCl}_{2}+0.1 \mathrm{M} \mathrm{NH}_{4} \mathrm{Cl}\right)+$ compound IV } \\
\hline 0.0 ppm compound IV & 384 & 211 & 1045 & 30.2 & -- \\
\hline 200 ppm compound IV & 533 & 265 & 1040 & 16.4 & 45.5 \\
\hline 400 ppm compound IV & 631 & 276 & 1040 & 11.3 & 62.5 \\
\hline 600 ppm compound IV & 679 & 293 & 1039 & 8.9 & 70.5 \\
\hline 800 ppm compound IV & 746 & 343 & 1039 & 7.5 & 75.1 \\
\hline 1000 ppm compound IV & 761 & 329 & 1039 & 6.1 & 79.8 \\
\hline
\end{tabular}




\section{Mechanism of inhibition}

The possible explanation of the inhibition is due to adsorption process which is considered as the key of the mechanism of inhibition action. It might be suggested that the inhibitor molecules adhere to the zinc electrode surface. This leads to a decrease of the surface area at which cathodic and anodic reactions take place. At one and the same inhibitor concentration, the values of inhibition efficiency decreased in the following order: Compound IV > Compound III > Compound II > Compound. This order reflects the increased tendency of these compounds to act as corrosion inhibitors by increasing the ethylamine units per molecule. The adsorption of the surfactant molecules takes place through their hydrophilic parts which usually contain the active groups. As a result of this behavior, the hydrocarbon tail, which is hydrophobic, is forced towards the aqueous solution side. These tails repel the water and aggressive molecules out from the surface and thus decrease their corrosion effects. As a fact, the surfactant compounds used in the present study are cationic. Thus, a positive charge is created at their heads upon dissolved in water. The presence of this positive charge may leading to increase the strength of adsorption of the head part at the anode surface. At the same time the repulsion force between water molecules and hydrocarbon chain tends to push the latter towards the metal surface. These two effects lead to one possible orientation of the surfactant molecules on the metal surface which is horizontal. So, one may expect that the used cationic surfactants adsorbed horizontally on the zinc electrode surface. In this case the effect of ethylamine becomes more important as seen from the obtained sequence. Thus, the inhibition efficiency increases as the number of ethylamine unit is increased.

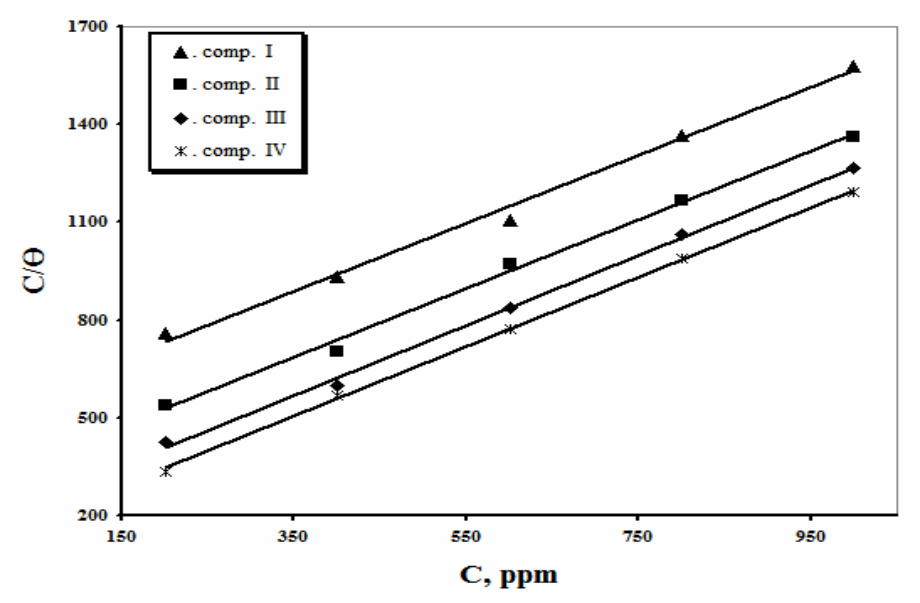

Figure 2. The relation between $\mathrm{C} / \Theta$ and $\mathrm{C}$ for compounds (I-IV) in $0.1 \mathrm{M} \mathrm{ZnCl}_{2}$.

\section{Adsorption isotherm}

The degree of surface coverage $(\Theta)$ of zinc surface by the adsorbed of amidopoly ethylamine compounds is calculated at constant potential using the following equation [25]:

$$
\Theta=1-\left(i_{\text {add }} / i_{\text {free }}\right)
$$


where, $i_{\text {free }}$ and $i_{\text {add }}$ are the corrosion current densities in absence and presence of the additive compounds, respectively. The degree of surface coverage $\theta$ is found to increase with increasing concentration of the additives. Plotting of $\mathrm{C} / \Theta$ against concentration of inhibitor (C) gives straight lines with unit slopes. [Figs (2-4)], This indicates that the adsorption of the inhibitors takes place following Langmuir adsorption isotherm. This isotherm postulates that there is no interaction between the adsorbed molecules and the adsorption free energy is independent of $\Theta$ value.

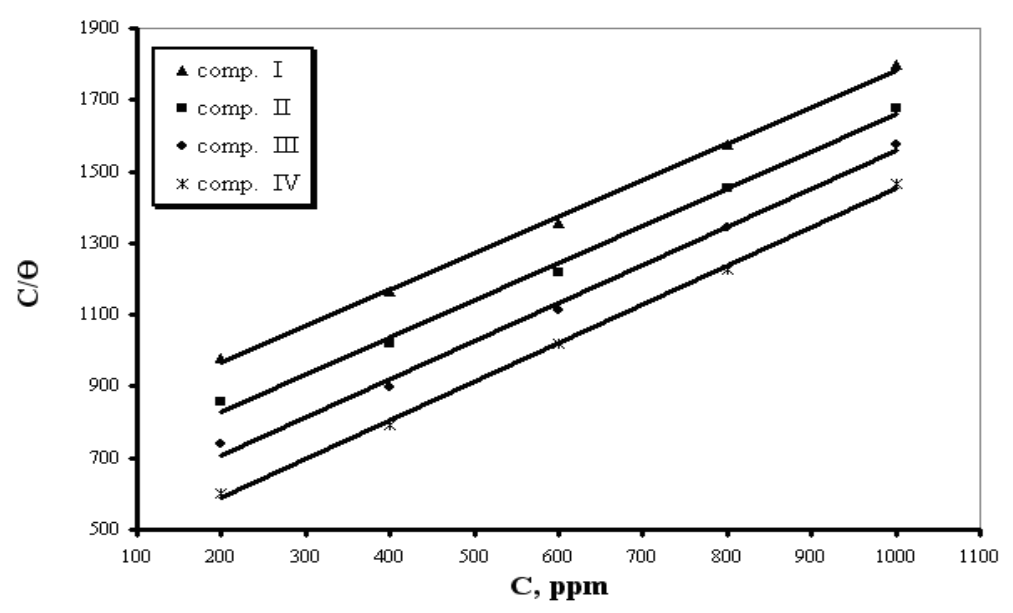

Figure 3. The relation between $\mathrm{C} / \Theta$ and $\mathrm{C}$ for compounds (I-IV) in $0.1 \mathrm{M} \mathrm{NH}_{4} \mathrm{Cl}$.

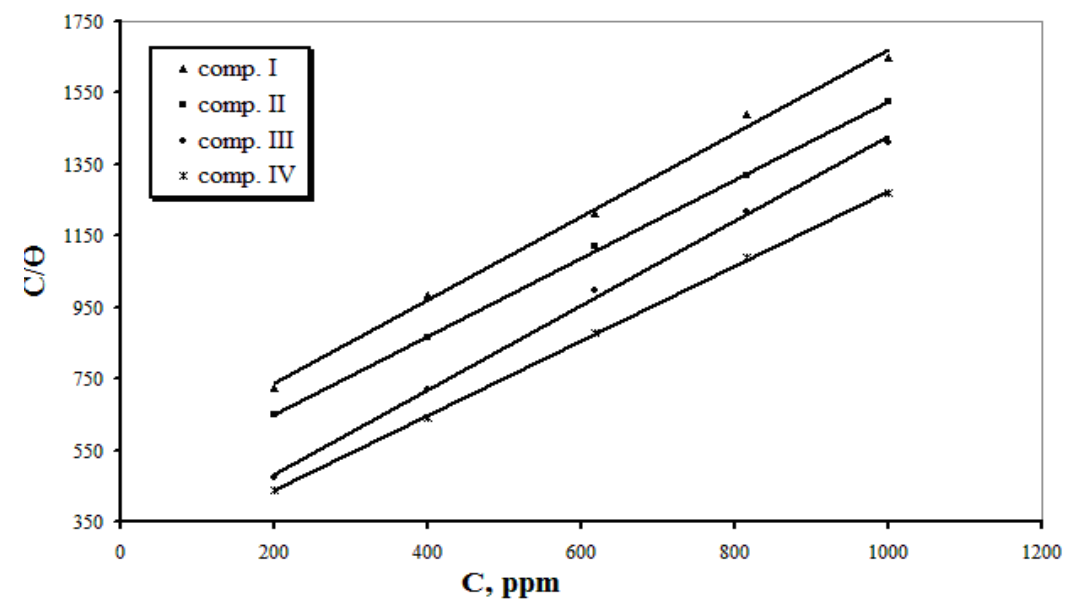

Figure 4. The relation between $\mathrm{C} / \Theta$ and $\mathrm{C}$ for compounds (I-IV) in $\left(0.1 \mathrm{M} \mathrm{NH}_{4} \mathrm{Cl}+0.1\right.$ $\mathrm{M} \mathrm{ZnCl}_{2)}$.

\section{Effect of temperature}

The effect of temperature on the corrosion parameters such as $i_{\text {corr }}, E_{\text {corr }}$ and IE was studied in $0.1 \mathrm{M} \mathrm{ZnCl}_{2}, 0.1 \mathrm{M} \mathrm{NH}_{4} \mathrm{Cl}$ and $\left(0.1 \mathrm{M} \mathrm{ZnCl}_{2}+0.1 \mathrm{M} \mathrm{NH} \mathrm{NH}_{4} \mathrm{Cl}\right.$ solutions, devoid and containing $1000 \mathrm{ppm}$ of inhibitors over the temperature ranges of $25-65{ }^{\circ} \mathrm{C}$. The results showed that the variation of temperature had almost no effect on the shape of the polarization curves. The data listed in Tables 4-6 show that, $E_{\text {corr }}$ shifted to less negative values whereas the values of $i_{\text {corr }}$ increased with the increase in temperature. This indicates the accelerating effect 
of rising temperature on the corrosion reaction. On the other hand, the increase in temperature led to a decrease in the inhibition efficiencies of all the tested compounds. It is clear from Tables 4-6 that the best inhibition efficiencies are obtained at $25{ }^{\circ} \mathrm{C}$.

Table 4. Effect of temperature on the corrosion parameters of $\mathrm{Zn}$ electrode in $0.1 \mathrm{M}$ $\mathrm{ZnCl}_{2}$ and $0.1 \mathrm{M} \mathrm{ZnCl}_{2}+1000$ ppm of inhibitors.

\begin{tabular}{|c|c|c|c|}
\hline $\mathbf{T}(\mathbf{K})$ & $\begin{array}{c}-\mathbf{E}_{\text {corr. }} \\
\mathrm{mV}(\mathrm{SCE})\end{array}$ & $\begin{array}{c}\mathbf{i}_{\text {corr. }} \times \mathbf{1 0}^{-1} \\
(\mathrm{~mA})\end{array}$ & $\begin{array}{l}\text { I.E. } \\
(\%)\end{array}$ \\
\hline \multicolumn{4}{|l|}{$0.1 \mathrm{M} \quad \mathrm{ZnCl}_{2}$} \\
\hline 298 & 1046 & 33.5 & -- \\
\hline 308 & 1040 & 40.7 & -- \\
\hline 318 & 1038 & 56.2 & -- \\
\hline 328 & 1035 & 70.2 & -- \\
\hline 338 & 1021 & 103.9 & -- \\
\hline \multicolumn{4}{|c|}{$0.1 \mathrm{M} \mathrm{ZnCl}_{2}+$ compound I } \\
\hline 298 & 1039 & 12.3 & 63.2 \\
\hline 308 & 1044 & 20.2 & 50.3 \\
\hline 318 & 1038 & 27.8 & 50.5 \\
\hline 328 & 1025 & 42.6 & 39.3 \\
\hline 338 & 1021 & 66.3 & 36.1 \\
\hline \multicolumn{4}{|c|}{$0.1 \mathrm{M} \mathrm{ZnCl} 2+$ compound II } \\
\hline 298 & 1033 & 8.9 & 73.4 \\
\hline 308 & 1045 & 16.6 & 59.2 \\
\hline 318 & 1039 & 24.5 & 56.4 \\
\hline 328 & 1027 & 39.0 & 44.4 \\
\hline 338 & 1021 & 57.6 & 44.5 \\
\hline \multicolumn{4}{|c|}{$0.1 \mathrm{M} \mathrm{ZnCl}_{2}+$ compound III } \\
\hline 298 & 1031 & 7.1 & 78.8 \\
\hline 308 & 1034 & 11.6 & 71.4 \\
\hline 318 & 1033 & 20.3 & 63.8 \\
\hline 328 & 1027 & 29.9 & 57.4 \\
\hline 338 & 1021 & 49.5 & 52.3 \\
\hline \multicolumn{4}{|c|}{$0.1 \mathrm{M} \mathrm{ZnCl} l_{2}+$ compound IV } \\
\hline 298 & 1017 & 5.4 & 84.0 \\
\hline 308 & 1033 & 8.4 & 79.3 \\
\hline 318 & 1032 & 14.3 & 74.5 \\
\hline 328 & 1027 & 25.2 & 64.1 \\
\hline 338 & 1026 & 41.6 & 59.5 \\
\hline
\end{tabular}


Table 5. Effect of temperature on the corrosion parameters of $\mathrm{Zn}$ electrode in $0.1 \mathrm{M}$ $\mathrm{NH}_{4} \mathrm{Cl}$ and $0.1 \mathrm{M} \mathrm{NH}_{4} \mathrm{Cl}+1000 \mathrm{ppm}$ of inhibitors.

\begin{tabular}{|c|c|c|c|}
\hline $\mathbf{T}(\mathbf{K})$ & $\begin{array}{c}-\mathbf{E}_{\text {corr. }} \\
\mathrm{mV}(\mathrm{SCE})\end{array}$ & $\begin{array}{c}\mathbf{i}_{\text {corr. }} \times \mathbf{1 0}^{-3} \\
(\mathrm{~mA})\end{array}$ & $\begin{array}{l}\text { I.E. } \\
(\%)\end{array}$ \\
\hline \multicolumn{4}{|l|}{$0.1 \mathrm{M} \mathrm{NH}_{4} \mathrm{Cl}$} \\
\hline 298 & 1145 & 39.9 & -- \\
\hline 308 & 1131 & 50.7 & -- \\
\hline 318 & 1117 & 64.7 & -- \\
\hline 328 & 1106 & 81.7 & -- \\
\hline 338 & 1085 & 95.1 & -- \\
\hline \multicolumn{4}{|c|}{$0.1 \mathrm{M} \mathrm{NH}_{4} \mathrm{Cl}+$ compound $\mathrm{I}$} \\
\hline 298 & 1122 & 17.7 & 55.6 \\
\hline 308 & 1108 & 22.7 & 55.2 \\
\hline 318 & 1104 & 31.0 & 52.0 \\
\hline 328 & 1102 & 39.9 & 51.1 \\
\hline 338 & 1093 & 47.2 & 50.3 \\
\hline \multicolumn{4}{|c|}{$0.1 \mathrm{M} \mathrm{NH}_{4} \mathrm{Cl}+$ compound II } \\
\hline 298 & 1130 & 16.1 & 59.6 \\
\hline 308 & 1113 & 20.6 & 59.3 \\
\hline 318 & 1102 & 26.4 & 59.1 \\
\hline 328 & 1099 & 34.4 & 57.9 \\
\hline 338 & 1089 & 43.2 & 54.5 \\
\hline \multicolumn{4}{|c|}{$0.1 \mathrm{M} \mathrm{NH}_{4} \mathrm{Cl}+$ compound III } \\
\hline 298 & 1123 & 14.6 & 63.4 \\
\hline 308 & 1092 & 18.6 & 63.3 \\
\hline 318 & 1085 & 24.7 & 61.7 \\
\hline 328 & 1076 & 32.4 & 60.3 \\
\hline 338 & 1071 & 40.9 & 56.9 \\
\hline \multicolumn{4}{|c|}{$0.1 \mathrm{M} \mathrm{NH}_{4} \mathrm{Cl}+$ compound IV } \\
\hline 298 & 1125 & 12.6 & 68.4 \\
\hline 308 & 1089 & 17.5 & 65.4 \\
\hline 318 & 1086 & 22.5 & 65.2 \\
\hline 328 & 1078 & 29.4 & 64.0 \\
\hline 338 & 1072 & 39.1 & 58.8 \\
\hline
\end{tabular}


Table 6. Effect of temperature on the corrosion parameters of $\mathrm{Zn}$ electrode in $(0.1 \mathrm{M}$ $\left.\mathrm{ZnCl}_{2}+0.1 \mathrm{M} \mathrm{NH}_{4} \mathrm{Cl}\right)$ and $\left(0.1 \mathrm{M} \mathrm{ZnCl}_{2}+0.1 \mathrm{M} \mathrm{NH}{ }_{4} \mathrm{Cl}\right)+1000$ ppm of inhibitors.

\begin{tabular}{|c|c|c|c|}
\hline $\mathbf{T}(\mathbf{K})$ & $\begin{array}{c}\mathbf{E}_{\text {corr. }} \\
\mathrm{mV}(\mathrm{SCE})\end{array}$ & $\begin{array}{c}\mathbf{i}_{\text {corr. }} \times 1^{-1} \\
(\mathrm{~mA})\end{array}$ & $\begin{array}{l}\text { I.E. } \\
(\%)\end{array}$ \\
\hline \multicolumn{4}{|c|}{$0.1 \mathrm{M} \mathrm{ZnCl}_{2}+0.1 \mathrm{M} \mathrm{NH}_{4} \mathrm{Cl}$} \\
\hline 298 & 1045 & 30.2 & -- \\
\hline 308 & 1057 & 37.8 & -- \\
\hline 318 & 1054 & 44.0 & -- \\
\hline 328 & 1045 & 52.3 & -- \\
\hline 338 & 1039 & 60.0 & -- \\
\hline \multicolumn{4}{|c|}{$0.1 \mathrm{M} \mathrm{ZnCl}_{2}+0.1 \mathrm{M} \mathrm{NH}_{4} \mathrm{Cl}+$ compound I } \\
\hline 298 & 1039 & 11.8 & 60.9 \\
\hline 308 & 1051 & 15.0 & 60.3 \\
\hline 318 & 1049 & 17.5 & 60.2 \\
\hline 328 & 1045 & 21.0 & 59.8 \\
\hline 338 & 1033 & 24.2 & 59.6 \\
\hline \multicolumn{4}{|c|}{$0.1 \mathrm{M} \mathrm{ZnCl}_{2}+0.1 \mathrm{M} \mathrm{NH}_{4} \mathrm{Cl}+$ compound II } \\
\hline 298 & 1045 & 10.3 & 65.8 \\
\hline 308 & 1043 & 13.0 & 65.6 \\
\hline 318 & 1040 & 15.2 & 65.4 \\
\hline 328 & 1037 & 18.1 & 65.3 \\
\hline 338 & 1033 & 22.3 & 62.8 \\
\hline \multicolumn{4}{|c|}{$0.1 \mathrm{M} \mathrm{ZnCl}_{2}+0.1 \mathrm{M} \mathrm{NH} \mathrm{N}_{4} \mathrm{Cl}+$ compound III } \\
\hline 298 & 1039 & 8.8 & 70.8 \\
\hline 308 & 1048 & 11.1 & 70.6 \\
\hline 318 & 1040 & 13.5 & 69.3 \\
\hline 328 & 1040 & 16.5 & 68.4 \\
\hline 338 & 1039 & 20.6 & 65.6 \\
\hline \multicolumn{4}{|c|}{$0.1 \mathrm{M} \mathrm{ZnCl}_{2}+0.1 \mathrm{M} \mathrm{NH}_{4} \mathrm{Cl}+$ compound IV } \\
\hline 298 & 1039 & 6.1 & 79.8 \\
\hline 308 & 1048 & 8.5 & 77.5 \\
\hline 318 & 1040 & 11.4 & 74.0 \\
\hline 328 & 1040 & 14.9 & 71.5 \\
\hline 338 & 1039 & 18.2 & 69.6 \\
\hline
\end{tabular}

The corrosion reaction is regarded as a rate process which is given by Arrhenius equation [6]

$$
\log \mathrm{R}_{\text {corr. }}=\log A-\mathrm{E}_{\mathrm{a}} / 2.303 \mathrm{RT}
$$


where $R_{\text {corr. }}$ is the rate constant of the metal dissolution reaction which is directly related to corrosion current density, $\mathrm{i}_{\text {corr. }}$ [26], $A$ is the frequency factor, $\mathrm{T}$ is the absolute temperature and $\mathrm{E}_{\mathrm{a}}$ is the activation energy. By plotting $\log \mathrm{R}_{\text {corr. }}$ versus $(1 / T)$, the values of $E_{a}$ can be calculated from the slope of the obtained straight lines [Figs. 5-7].

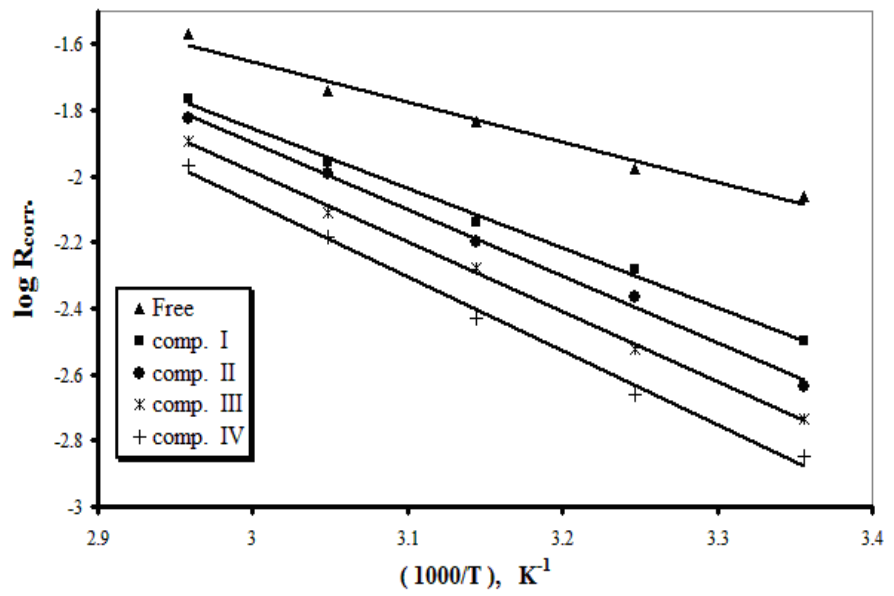

Figure 5. Arrhenius plots of zinc corrosion rate in $0.1 \mathrm{M} \mathrm{ZnCl}_{2}$ in absence and presence of 1000 ppm of compounds (I-IV).

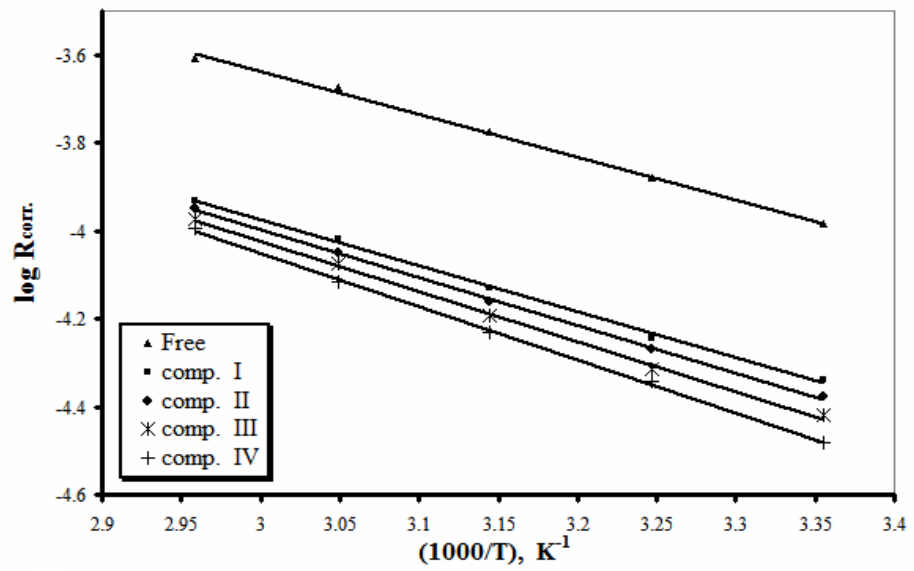

Figure 6. Arrhenius plots of zinc corrosion rate in $0.1 \mathrm{M} \mathrm{NH} \mathrm{NH}_{4} \mathrm{Cl}$ in absence and presence of $1000 \mathrm{ppm}$ of compounds (I-IV).

An alternative formulation of the Arrhenius equation is the transition state equation [6]

$$
\log \left(\mathrm{R}_{\mathrm{corr}} / \mathrm{T}\right)=\left[\log (\mathrm{R} / \mathrm{Nh})+\left(\Delta \mathrm{S}^{*} / 2.303 \mathrm{R}\right)\right]-\Delta \mathrm{H}^{*} / 2.303 \mathrm{RT}
$$

where $\mathrm{h}$ is Planck's constant, $\mathrm{N}$ is Avogadro's number, $\Delta \mathrm{S}^{*}$ is the entropy of activation and $\Delta \mathrm{H}^{*}$ is the enthalpy of activation. 


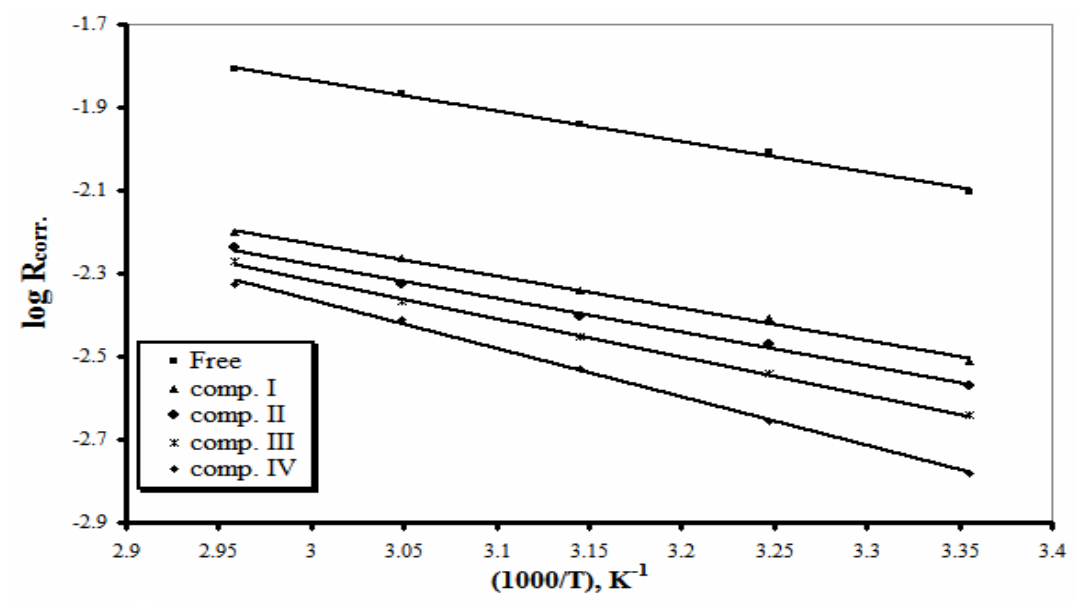

Figure 7. Arrhenius plots of zinc corrosion rate in a solution of $\left(0.1 \mathrm{M} \mathrm{NH}_{4} \mathrm{Cl}+0.1 \mathrm{M}\right.$ $\mathrm{ZnCl}_{2}$ ) in absence and presence of $1000 \mathrm{ppm}$ of compounds (I-IV).

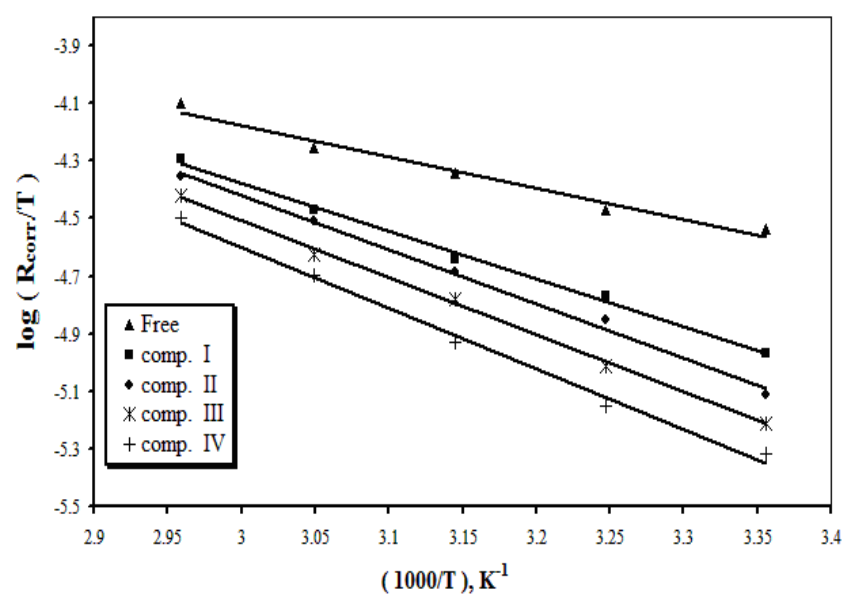

Figure 8. The relation between $\log \left(\mathrm{R}_{\text {corr }} / \mathrm{T}\right)$ and $(1 / \mathrm{T})$ for zinc electrode in $0.1 \mathrm{M} \mathrm{ZnCl}_{2}$, in absence and presence of $1000 \mathrm{ppm}$ of compounds (I-IV).

Figs. 8-10 show a plot of $\log \left(\mathrm{R}_{\text {corr }} / \mathrm{T}\right)$ against $(1 / \mathrm{T})$. Straight lines are obtained with a slope of $\left(-\Delta \mathrm{H}^{*} / 2.303 \mathrm{R}\right)$, and an intercept of $\left(\log [\mathrm{R} / \mathrm{Nh}]+\Delta \mathrm{S}^{*} / 2.303 \mathrm{R}\right)$ from which the values of $\Delta \mathrm{H}^{*}$ and $\Delta \mathrm{S}^{*}$ were calculated are listed in Table 7. The data show that the activation parameters $\left(\mathrm{E}_{\mathrm{a}}, \Delta \mathrm{H}^{*}, \Delta \mathrm{S}^{*}\right)$ of the dissolution of zinc electrode in all solutions in the presence of $1000 \mathrm{ppm}$ of the four studied compounds increased more than those of the uninhibited solution. The presence of the tested compounds increased the activation energy values and consequently decreased the corrosion rate of the zinc electrode. Furthermore, $E_{a}$ increases with the increased in ethylamine units per the inhibitor molecule. These findings indicate that amidopoly ethylamine compounds acted as inhibitors through increasing the activation energy of zinc electrode dissolution by making a barrier to mass and charge transfer by their adsorption on zinc electrode surface. The positive values of $\Delta \mathrm{H}^{*}$ reflect a strong chemisorptions of the inhibitor on the zinc electrode surface. The values of entropy of activation $\Delta S^{*}$ in the absence and in the presence of the studied compounds are negative. This implies that the activated complex in the rate determining step represents an association rather 
than a dissociation step [25]. This means that the activated molecules are in higher order state than that at the initial stage.

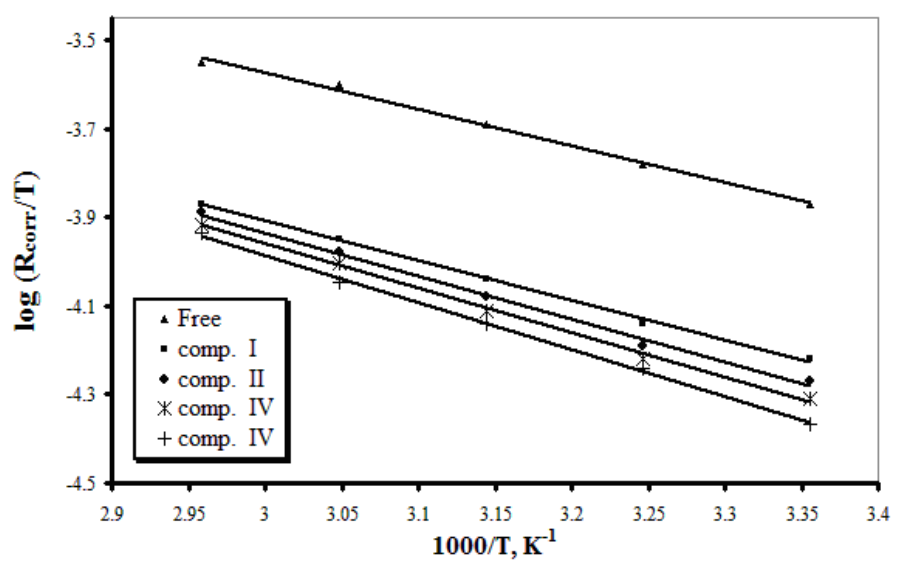

Figure 9. The relation between $\log \left(\mathrm{R}_{\text {corr }} / \mathrm{T}\right)$ and $(1 / \mathrm{T})$ for zinc electrode in $0.1 \mathrm{M}$ $\mathrm{NH}_{4} \mathrm{Cl}$, in absence and presence of $1000 \mathrm{ppm}$ of compounds (I-IV).

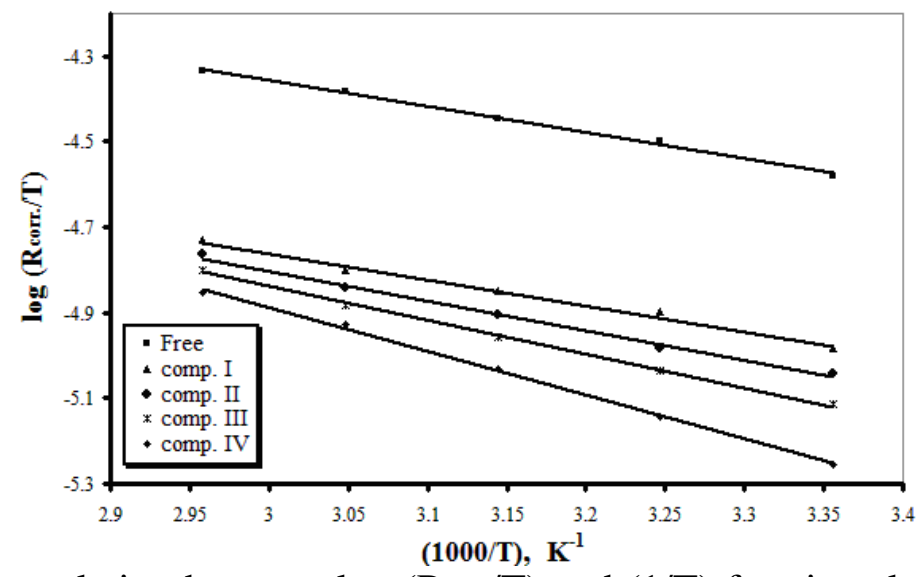

Figure 10. The relation between $\log \left(\mathrm{R}_{\text {corr }} / \mathrm{T}\right)$ and $(1 / \mathrm{T})$ for zinc electrode in a solution $\left(0.1 \mathrm{M} \mathrm{NH}_{4} \mathrm{Cl}+0.1 \mathrm{M} \mathrm{ZnCl}_{2}\right.$ ), in absence and presence of $1000 \mathrm{ppm}$ of compounds (IIV).

\section{Conclusions}

1. The value of $\mathrm{i}_{\text {corr. }}$ in case of $\left(\mathrm{ZnCl}_{2}+\mathrm{NH}_{4} \mathrm{Cl}\right)$ is higher than that obtained in $\mathrm{NH}_{4} \mathrm{Cl}$ and less than that obtained in $\mathrm{ZnCl}_{2}$ of the same concentration. This indicates that, both $\mathrm{ZnCl}_{2}$ and $\mathrm{NH}_{4} \mathrm{Cl}$ accelerate the corrosion of zinc electrode. The combined effect of $\mathrm{ZnCl}_{2}$ and $\mathrm{NH}_{4} \mathrm{Cl}$ on the corrosion of zinc electrode is greater than that caused by $\mathrm{NH}_{4} \mathrm{Cl}$ and less than that caused by $\mathrm{ZnCl}_{2}$.

2. The amidopoly ethylamines are considered as inhibitors for zinc electrode corrosion in $0.1 \mathrm{M} \mathrm{ZnCl}_{2}, 0.1 \mathrm{M} \mathrm{NH}_{4} \mathrm{Cl}$ and $\left(0.1 \mathrm{M} \mathrm{ZnCl}_{2}+0.1 \mathrm{M} \mathrm{NH}_{4} \mathrm{Cl}\right)$ 
solutions. The inhibition efficiency is found to increase by increasing the inhibitor concentrations, number of ethylamine unit and/or decreasing of the temperature.

3. The inhibitive action of these compounds takes place through the adsorption of their molecules on the zinc electrode surface.

4. The adsorption of these compounds on a zinc electrode surface obeyed the Langmuir adsorption isotherm.

Table 7. Activation parameters of the dissolution reaction of zinc electrode in $0.1 \mathrm{M}$ $\mathrm{ZnCl}_{2}, 0.1 \mathrm{M} \mathrm{NH} 4 \mathrm{Cl}$ and $\left(0.1 \mathrm{M} \mathrm{ZnCl}_{2}+0.1 \mathrm{M} \mathrm{NH} \mathrm{Nl}_{4}\right)$ solutions in absence and presence of $1000 \mathrm{ppm}$ of the amidopoly ethylamine compounds.

\begin{tabular}{|c|c|c|c|}
\hline concentration & $\begin{array}{c}\mathbf{E}_{\mathbf{a}} \\
\left(\mathrm{kJ} \cdot \mathrm{mol}^{-1}\right)\end{array}$ & $\begin{array}{c}\Delta \mathbf{H}^{*} \\
\left(\mathrm{~kJ} \cdot \mathrm{mol}^{-1}\right)\end{array}$ & $\begin{array}{c}-\Delta \mathbf{S}^{*} \\
\left(\mathrm{~J} \cdot \mathrm{mol}^{-1} \cdot \mathrm{K}^{-1}\right)\end{array}$ \\
\hline $0.1 \mathrm{M} \mathrm{ZnCl}_{2}$ & 23.8 & 20.5 & 141.3 \\
\hline $0.1 \mathrm{M} \mathrm{ZnCl}_{2}+1000 \mathrm{ppm}$ compound I & 35.6 & 31.2 & 143.9 \\
\hline $0.1 \mathrm{M} \mathrm{ZnCl}_{2}+1000 \mathrm{ppm}$ compound II & 39.6 & 34.6 & 144.4 \\
\hline $0.1 \mathrm{M} \mathrm{ZnCl}_{2}+1000 \mathrm{ppm}$ compound III & 42.4 & 37.1 & 145.9 \\
\hline $0.1 \mathrm{M} \mathrm{ZnCl}_{2}+1000 \mathrm{ppm}$ compound IV & 46.1 & 39.7 & 147.3 \\
\hline $0.1 \mathrm{M} \mathrm{NH}_{4} \mathrm{Cl}$ & 18.9 & 15.4 & 130.3 \\
\hline $0.1 \mathrm{M} \mathrm{NH}_{4} \mathrm{Cl}+1000 \mathrm{ppm}$ compound I & 20.5 & 17.1 & 136.6 \\
\hline $0.1 \mathrm{M} \mathrm{NH}_{4} \mathrm{Cl}+1000 \mathrm{ppm}$ compound II & 21.3 & 18.5 & 137.0 \\
\hline $0.1 \mathrm{M} \mathrm{NH}_{4} \mathrm{Cl}+1000 \mathrm{ppm}$ compound III & 22.3 & 18.8 & 137.4 \\
\hline $0.1 \mathrm{M} \mathrm{NH}_{4} \mathrm{Cl}+1000 \mathrm{ppm}$ compound IV & 23.7 & 20.2 & 137.8 \\
\hline$\left(0.1 \mathrm{M} \mathrm{ZnCl}_{2}+0.1 \mathrm{M} \mathrm{NH}_{4} \mathrm{Cl}\right)$ & 14.7 & 11.2 & 145.9 \\
\hline$\left(0.1 \mathrm{M} \mathrm{ZnCl}_{2}+0.1 \mathrm{M} \mathrm{NH}_{4} \mathrm{Cl}\right)+1000 \mathrm{ppm}$ compound I & 16.4 & 11.5 & 153.5 \\
\hline$\left(0.1 \mathrm{M} \mathrm{ZnCl}_{2}+0.1 \mathrm{M} \mathrm{NH}_{4} \mathrm{Cl}\right)+1000 \mathrm{ppm}$ compound II & 16.9 & 12.8 & 154.1 \\
\hline$\left(0.1 \mathrm{M} \mathrm{ZnCl}_{2}+0.1 \mathrm{M} \mathrm{NH}_{4} \mathrm{Cl}\right)+1000 \mathrm{ppm}$ compound III & 18.6 & 14.4 & 154.7 \\
\hline$\left(0.1 \mathrm{M} \mathrm{ZnCl}_{2}+0.1 \mathrm{M} \mathrm{NH}_{4} \mathrm{Cl}\right)+1000 \mathrm{ppm}$ compound IV & 22.8 & 19.0 & 155.2 \\
\hline
\end{tabular}

\section{References}

1. Y. Ein-Eli, M. Auinat, D. Straosvetsky, J. Power Sources 114 (2003) 330.

2. Q. Qu, L. Li, W. Bai, C. Yan, C. Cao, Corr. Sci. 47 (2005) 2832.

3. D. Zhang, L. Lidong, L. Cao, N. Yang, C. Huang, Corr. Sci. 43 (2001) 1627.

4. K. Orubite Okorosaye, N.C. Oforka, J. Appl. Sci. Environ. Mgt. 8 (2004) 57. 
5. Y.K. Agrawal, J.D. Talati, M.D. Shah, M.N. Desai, N.K. Shah, Corr. Sci. 46 (2004) 633.

6. M. Abdallah, Corr. Sci. 45 (2003) 2705.

7. A.Y. El-Etre, M. Abdallah, Z.E. El-Tantawy, Corr. Sci. 47 (2005) 385.

8. E.E. Foad El-Sherbini, S.M. Abdel Wahaab, M. Deyab, Mater. Chem. Phys. 89 (2005) 183.

9. L. Wang, J. Pu, H. Luo, Corr. Sci. 45 (2003) 677.

10. S.K. Rajappa, T.V. Venkatesha, Turk. J .Chem. 27 (2003) 189.

11. J.D. Talati, M.N. Desai, N.K. Shah, Mater. Chem. Phys. 93 (2005) 54.

12. S. Magaino, M. Soga, K. Sobue, A. Kawaguchi, N. Ishida, H. Imai, Electrochim. Acta 44 (1999) 4307.

13. M.S. Morad, J. Appl. Electrochem. 29 (1999) 619.

14. A.M. Gad Allah, M.M. Hefiny, S.A. Salim, M.S. El-Basiouny, Corr. 45 (1989) 574.

15. B. Muller, G. Inblo, Corr. Sci. 38 (1996) 293.

16. A.A. Abdel Fattah, E.M. Mabrouk, R.M. Abd El Gulil, M.M. Ghoneim, Bull. Soc. Chim. Fr. 127 (1991) 98.

17. R. Sethumodbavan, S. Manavlan, S. Subramanian, H.D. Christopher, Bull. Electrochem. 8 (1992) 101.

18. M.S. Abdel Aal, Z.A. Ahmed, M.S. Hassan, J. Appl. Electrochem. 22 (1992) 1104.

19. F. Basio, R.G. Poarson, Mechanism of Inorganic Reaction, $2^{\text {nd }}$ ed., John Wiley, London, 1967.

20. L.L. Shreir (Ed.), Corrosion, $2^{\text {nd }}$ ed., vol. 2, Newnes-Butterworth, London, 1977, pp. 18.2-18.3.

21. Y. Kumar, D. Dhirandra, B. Sanyal, G.N. Pandey, Met. Finish. 45 (1983) 81.

22. R.L. Every, O.L. Riggs, Mater. Prot. 3 (1964) 46.

23. W.I.A. El Dougdoug, Grasas Y. Aceites (Spain) 50(5) 385 (1999).

24. F. Hanna, G.M. Sherbini, Y. Barakat, Br. Corr. J. 17 (1982) 131.

25. I.A. Ammer, S. Darwish, Corr. Sci. 7 (1967) 679.

26. K.J. Laider, Chemical Kinetics, Mc-Graw-Hill Publishing. 